\section{Immobilization of Glucose Oxidase on Eupergit C: Impact of Aeration, Kinetic and Operational Stability Studies of Free and Immobilized Enzyme}

\author{
D. Pečar, ${ }^{a}$ Đ. Vasić-Rački, ${ }^{b}$ and A. Vrsalović Presečki ${ }^{\text {b," }}$ \\ anniversity of Maribor, Faculty of Chemistry and Chemical Engineering, \\ Smetanova 17, SI-2000 Maribor, Slovenia \\ bUniversity of Zagreb, Faculty of Chemical Engineering and Technology, \\ Savska c. 16, HR-10000 Zagreb, Croatia
}

doi: 10.15255/CABEQ.2018.1391

Original scientific paper

Received: May 29, 2018

Accepted: December 5, 2018

\begin{abstract}
The effect of aeration on the stability of glucose oxidase in the reaction of glucose oxidation to gluconic acid was investigated by determining the operational stability decay rate constant in the process conditions. Eupergit $\mathrm{C}$ as a porous carrier was chosen for the enzyme immobilization. To evaluate glucose oxidase operational stability during process conditions, experiments of glucose oxidation were carried out in the repetitive batch reactor with and without continuous aeration at different aeration levels. It was found that the decay rate of the free enzyme linearly depended on the air flow rate. Immobilization of glucose oxidase on Eupergit $\mathrm{C}$ significantly enhanced enzyme stability at higher aeration rates. Kinetics of the free and immobilized enzyme was also determined. The mathematical model of glucose oxidation catalysed by free and immobilized glucose oxidase in the batch reactor was developed.
\end{abstract}

Keywords:

glucose oxidase, immobilization, oxygen mass transfer, enzyme stability, kinetics, mathematical modelling

\section{Introduction}

Enzymatic oxidation is an important reaction for production of valuable products ${ }^{1}$. The advantages over chemical oxidation are high selectivity and low environmental impact, since enzymes are active under mild conditions ${ }^{2}$. In addition, biocatalytic oxidations use oxygen as the electron acceptor, which is easily available and inexpensive. The limitation considering oxygen utilisation is its slow mass transfer from air to aqueous phase. In order to overcome this problem, a continuous supply of oxygen in the reactor is necessary to achieve reasonable reaction rates. The method for oxygen delivery usually causes irreversible enzyme inactivation, which is commonly attributed to the hydrodynamic shear stress and gas-liquid interface ${ }^{2}$.

Glucose oxidase (GOD) belongs to the glucose/ methanol/choline (GMC) oxidoreductase family. It is a dimeric protein consisting of two identical $80 \mathrm{kDa}$ subunits that contain non-covalently bound flavin adenine dinucleotide (FAD) per monomer as cofactor at the active site $^{3}$. Glucose oxidase is widely employed in food industry due to its ability to remove glucose and oxygen $\left(\mathrm{O}_{2}\right)$ or to produce glu-

"Corresponding author: Ana Vrsalović Presečki,

e-mail: avrsalov@fkit.hr conic acid ${ }^{4}$. It is also used in chemical, pharmaceutical, textile, and other biotechnological industries. GOD catalyses the oxidation of D-glucose using atomic $\mathrm{O}_{2}$ as the electron acceptor to D-glucono- $\delta$ -lactone and hydrogen peroxide. D-Glucono- $\delta$-lactone is subsequently spontaneously hydrolysed to D-gluconic acid. The gluconic acid and its derivatives produced by GOD have application in food, pharmaceutical, textile and building industries. Currently, the gluconic acid production of approximately 100,000 ton/year is mostly by biotechnological processes $^{5}$. Despite the great interest for application in a variety of processes, the native GOD is unstable. Like other oxidase, GOD is inactivated by increasing gas-liquid interface, as well as the oxygen concentration in the medium ${ }^{6,7}$. Immobilization of GOD provides several benefits that include enhanced stability, easier separation of the product from the reaction medium, increased productivity, and possibility of enzyme reuse. Different methods as well different carriers were tested for GOD immobilization $^{8-13}$. Enzyme deactivation caused by aeration can be efficiently avoided by using porous support for immobilization ${ }^{7,14,15}$. These supports prevent any intermolecular process preventing the enzyme interaction with external interfaces ${ }^{16}$.

Eupergit $\mathrm{C}$ is widely used as a carrier for the immobilization of different enzymes. It is extremely 
stable and possesses good chemical and mechanical properties, such as simple immobilization procedure and high binding capacity ${ }^{17}$. Eupergit $\mathrm{C}$ is a naturally porous polymer ${ }^{18}$ and immobilization on it can be achieved without the need for additional reagents by forming strong covalent linkages between Eupergit epoxy groups and enzyme nucleophilic groups $^{19}$. A high density of epoxy groups on the Eupergit surface enables the multipoint attachment of the enzyme, resulting in enhanced conformational stability and long-term operational stability.

Since the main obstacle of these reactions is enzyme operational stability decay, the knowledge on biocatalyst stability is essential. Enzyme deactivation rate can vary differently with the system and operating conditions. Deactivation property of an enzyme, determined as a function at the relevant operating conditions, together with the mathematical model of the process can be used to predict the outcome of the process at different conditions ${ }^{11}$. This can help in developing a relevant industrial process $^{20}$.

In this paper, GOD was kinetically characterized in free form and immobilized on Eupergit $\mathrm{C}$ in the reaction of glucose oxidation to gluconic acid. For both forms of enzymes, the influence of oxygen on kinetics was investigated, and the mathematical model was proposed and validated in the batch reactor. The effect of aeration rates on the stability of free and immobilized GOD was examined by determination of operational stability decay constant. Catalase was added to the process to eliminate hydrogen peroxide, which is also a product of glucose catalysed GOD oxidation and can inactivate the enzyme.

\section{Experimental}

\section{Chemicals}

Catalase from Micrococcus lysodeikticus $\left(65,000-150,000\right.$ units $\mathrm{cm}^{-3}$ E.C. 1.11.1.6), o-dianisidin and Eupergit $\mathrm{C}(150 \mu \mathrm{m}$ spherical particles, binding capacity $50 \mathrm{mg}_{\text {protein }}$ per $\mathrm{g}$ of carrier, water binding capacity $4 \mathrm{~cm}^{3}$ per $\mathrm{g}$ of carrier) were purchased from Fluka, Germany. Glucose, gluconic acid, D-glucono- $\delta$-lactone, glucose oxidase from Aspergillus niger (powder, $\geq 100$ units $\mathrm{g}^{-1}$, E.C. 1.1.3.4), and peroxidase from horse radish (lyophilized powder, 250-330 units $\mathrm{mg}^{-1}$, E.C. 1.11.1.7) were purchased from Sigma Aldrich, Germany. $\mathrm{Na}_{2} \mathrm{HPO}_{4}$ and $\mathrm{KH}_{2} \mathrm{PO}_{4}$ were purchased from Kemi$\mathrm{ka}$, Croatia. Nitrogen was purchased from Messer, Croatia. Glucose-PAP colorenzymatic test was obtained from Dijagnostika, Croatia.

\section{Immobilization of glucose oxidase and catalase}

The enzyme immobilization on Eupergit $\mathrm{C}$ is simple because Eupergit is already a prepared carrier. A mass of $1 \mathrm{~g}$ of Eupergit $\mathrm{C}$ was mixed with $5 \mathrm{~cm}^{3}$ of glucose oxidase solution $\left(\gamma_{\mathrm{GOD}}=2 \mathrm{mg} \mathrm{cm}^{-3}\right)$ in phosphate buffer $(0.1 \mathrm{M}, \mathrm{pH} 7)$. The same amount of Eupergit $\mathrm{C}$ was mixed with a solution of catalase $\left(\varphi_{\text {catalase }}=0.08\right)$ in phosphate buffer $(0.1 \mathrm{M}, \mathrm{pH} 7)$. Stitring was carried out on a shaker for 72 hours at room temperature (slow stirring at $80 \mathrm{rpm}$ ). It was then centrifuged, and the carrier with immobilized enzyme was washed with phosphate buffer $(0.1 \mathrm{M}$, $\mathrm{pH} 7$ ). The success of enzyme immobilization was evaluated by the immobilisation yield, the immobilisation efficiency, and the activity recovery (Eqs. $(-3)^{21}$. They were calculated as follows:

$$
\text { Yield }=\frac{\text { immobilised activity }}{\text { starting activity }}
$$

The immobilised activity was calculated by subtracting the total residual enzyme activity after the immobilisation from the total starting activity.

$$
\text { Efficiency }=\frac{\text { observed activity }}{\text { immobilised activity }}
$$

The observed activity is the activity of the immobilised enzyme.

$$
\text { Activity recovery }=\frac{\text { observed activity }}{\text { starting activity }}
$$

\section{Analytical methods}

Gluconic acid and D-glucono- $\delta$-lactone were followed by HPLC (Shimadzu) with APS Hypersil column (Hewlett Packard, $5 \mu \mathrm{m}, 200$ x $4.6 \mathrm{~mm}$ ) at $210 \mathrm{~nm}$. The mobile phase was water with the addition of perchloric acid ( $\mathrm{pH} 2.10-2.15)$ at a flow rate $0.9 \mathrm{~cm}^{3} \mathrm{~min}^{-1}$. The analysis was performed at $30{ }^{\circ} \mathrm{C}$. Retention times of D-glucono- $\delta$-lactone and gluconic acid were 2.8 and $9.25 \mathrm{~min}$, respectively.

Glucose concentration was determined by standard colorenzymatic method (GOD/PAP).

Oxygen concentration was measured by fibre optic oxygen sensor (FireSting $\mathrm{O}_{2}$, PyroScience $\mathrm{GmbH}$, Aachen, Germany), which showed the level of oxygen saturation in percent. It was calibrated before using it at given working conditions $(0.1 \mathrm{M}$ phosphate buffer $\mathrm{pH} 7,30^{\circ} \mathrm{C}$ ) at two points (without oxygen that was removed by nitrogen and at oxygen saturation level). To recalculate oxygen percent to $\mathrm{mM}$, literature data were used ${ }^{22}$.

The enzymatic activity of free and immobilized GOD was determined according to the peroxidase-o-dianisidin assay using D-glucose as a substrate. The reaction mixture contained buffer-glu- 
cose solution (0.1 M phosphate buffer ( $\mathrm{pH} 7)$, $o$-dianisidin $(7.66 \mathrm{mM})$, peroxidase $\left(1796.5 \mathrm{U} \mathrm{cm}^{-3}\right)$ suspended in ammonium sulphate solution $(3.2 \mathrm{M})$, and enzyme GOD solution at the final volume of $1 \mathrm{~cm}^{3}$. The mixture without GOD was preincubated at $30{ }^{\circ} \mathrm{C}$ and saturated with oxygen. The reaction started by addition of GOD solution. The change in absorbance at $436 \mathrm{~nm}$ was monitored via spectrophotometer (Shimadzu, UV 1800). One unit of enzyme activity was defined as the amount of enzyme necessary to oxidise $1 \mu \mathrm{mol}$ of glucose per one minute at $30{ }^{\circ} \mathrm{C}$ and $\mathrm{pH} 7$.

Immobilized GOD activity was measured in a $2-\mathrm{cm}^{3}$ reactor that contained buffer-glucose solution (0.1 M phosphate buffer $\mathrm{pH} 7$ ) and the immobilized GOD. Samples were taken at regular intervals during the first 10 minutes of the reaction, and glucose concentration was determined. From the change in glucose concentration over time, the immobilized GOD activity was calculated.

Activity of free and immobilized catalase was measured by monitoring the decrease in hydrogen peroxide concentration at $240 \mathrm{~nm}$ via spectrophotometer ${ }^{23}$. One unit of enzyme activity was defined as the amount of enzyme necessary to decompose $1 \mu \mathrm{mol}$ of hydrogen peroxide per one minute at 30 ${ }^{\circ} \mathrm{C}$ and $\mathrm{pH} 7$.

\section{Determination of overall oxygen volumetric mass transfer coefficient, $k_{L} a$}

The overall oxygen volumetric mass transfer coefficient $\left(k_{L} a\right)$ was determined using the static gassing out method ${ }^{24}$ based on Eq. 4 .

$$
\frac{\mathrm{d} c_{\mathrm{O}_{2}}}{\mathrm{~d} t}=k_{L} a\left(c_{\mathrm{O}_{2}}^{*}-c_{\mathrm{O}_{2}}\right)
$$

The measurements were performed as follows: The liquid was deoxygenated by purging with nitrogen, and the deoxygenated liquid was then aerated and agitated. The increase in dissolved oxygen in the latter period was used for the determination of $k_{L} a$. Oxygen concentration was measured as described previously.

\section{Kinetics analysis}

Kinetic measurements were performed according to the initial reaction rate method in $0.1 \mathrm{M}$ phosphate buffer $\mathrm{pH} 7$ at $30^{\circ} \mathrm{C}$.

Impact of glucose and gluconic acid concentration on the initial reaction rate of free and immobilized GOD was measured using the activity test as described previously. The dependence of initial reaction rate on glucose concentration was measured by varying the glucose concentration $(0-300 \mathrm{mM})$, and keeping the oxygen concentration at the satura- tion level $\left(c_{\mathrm{O}_{2}}=0.1816 \mathrm{mM}\right)$. To determine the impact of gluconic acid on the initial reaction rate, gluconic acid was varied in the range $0-300 \mathrm{mM}$, while concentration of glucose and oxygen was constant and in the saturation level $\left(c_{\mathrm{O}_{2}}=0.1816 \mathrm{mM}\right.$, $\left.c_{\text {glucose }}=250 \mathrm{mM}\right)$. The dependence of free and immobilized GOD reaction rate on the oxygen concentration was determined by monitoring the oxygen concentration as described previously. The initial oxygen concentration was adjusted by combining flow of air and pure nitrogen, and the glucose concentration was kept constant at saturation level $\left(c_{\text {glucose }}=250 \mathrm{mM}\right)$. When the initial oxygen concentration was set to the desired value, the enzyme was added to start the reaction. Since oxygen was simultaneously consumed in the reaction and dissolved from air, Eq. (5) was used to estimate the initial reaction rate.

$$
\frac{\mathrm{d} c_{\mathrm{O}_{2}}}{\mathrm{~d} t}=k_{L} a\left(c_{\mathrm{O}_{2}}^{*}-c_{\mathrm{O}_{2}}\right)-r_{1}
$$

Kinetics of free and immobilized catalase was determined using the catalase activity test described previously, and by varying the $\mathrm{H}_{2} \mathrm{O}_{2}$ concentration $(0-60 \mathrm{mM})$.

\section{Reactor experiments}

Glucose oxidation catalysed by free and Eupergit-immobilized glucose oxidase was carried out with one or two glucose additions without aeration and with aeration at 15 and $30 \mathrm{dm}^{3} \mathrm{~h}^{-1}$ air flow rates. A $50-\mathrm{cm}^{3}$ reactor, placed on the magnetic stirrer at $600 \mathrm{rpm}$, was used for the experiments with free enzyme. Reactions catalysed by immobilized enzymes were performed in $30-\mathrm{cm}^{3}$ reactor on the shaker (100 rpm). Oxygen was supplied using air compressor. The air flow rate was adjusted using the air flow meter. Air was supplied through the perforated plastic ring air distributor $3 \mathrm{~cm}$ in diameter containing 15 uniformly distributed holes with a diameter $0.7 \mathrm{~mm}$. The reaction media was solution of glucose in $0.1 \mathrm{M}$ phosphate buffer $\mathrm{pH} 7.0$ at $30{ }^{\circ} \mathrm{C}$. The defined amount of free and immobilized GOD and catalase were added to the reactor to start the reaction. Concentrations of glucose, gluconic acid, D-glucono- $\delta$-lactone, and oxygen were monitored by the previously described methods. The enzyme activity was monitored during the experiments by the independent enzyme assay described above. Detailed reaction conditions are presented in the legends of Figs. 5-8.

\section{Mathematical model and data processing}

The mathematical model of glucose oxidation catalyzed by glucose oxidase from Aspergillus $n i$ - 

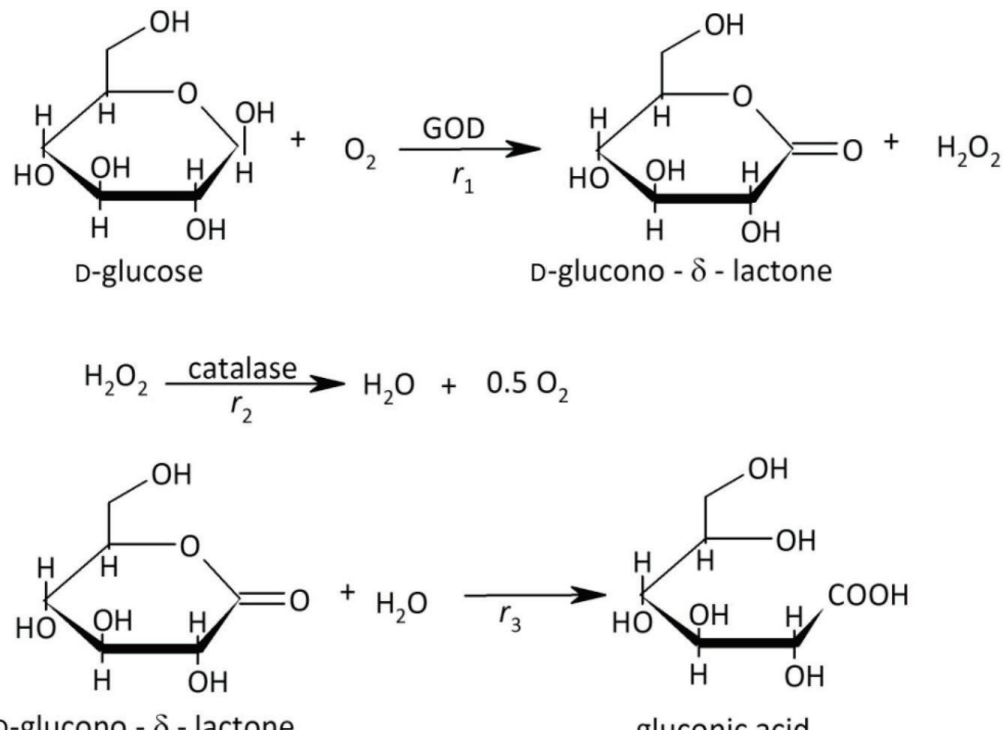

Fig. 1 - Reaction scheme

ger, consists of kinetic and mass balance equations in the batch reactor. The kinetic model was based on the reaction scheme (Fig. 1) and experimental results. The kinetics of the glucose oxidation reaction is described by two-substrate Michaelis-Menten model with competitive inhibition of the product (gluconic acid) (Eq. 6). The removal of hydrogen peroxide catalysed by catalase was described by kinetics of the first order due to the low specificity of catalase to hydrogen peroxide (high values of Michaelis-Menten constant) (Eq. 7). Spontaneous hydrolysis of glucono- $\delta$-lactone was described by n-order kinetic (Eq. 8).

$$
\begin{gathered}
r_{1}=\frac{V_{m} \cdot c_{\text {glucose }} \cdot c_{\mathrm{O}_{2}} \cdot \gamma_{\mathrm{GOD} \text { (eupergit) }}}{\left(K_{m}^{\text {glucose }} \cdot\left(1+\frac{c_{\text {gluconic acid }}}{K_{i}^{\text {gluconic acid }}}\right)+c_{\text {glucose }}\right)\left(K_{m}^{\mathrm{O}_{2}}+c_{\mathrm{O}_{2}}\right)} \\
r_{2}=\varphi_{\text {catalase }} \cdot k_{\text {catalase }} \cdot c_{\mathrm{H}_{2} \mathrm{O}_{2}} \\
r_{3}=k_{n} \cdot c_{\text {glucono-8- -lactone }}^{n}
\end{gathered}
$$

The reactor model for the batch reactor consists of the mass balance for glucose (Eq. 9), glucono- $\delta$-lactone (Eq. 10), gluconic acid (Eq. 11), oxygen (Eq. 12), and hydrogen peroxide (Eq. 13). The oxygen balance (Eq. 12) involves the dissolved oxygen in the reaction mixture during the experiment that takes place due to the controlled air supply or the direct contact with oxygen from the environment.

$$
\frac{\mathrm{d} c_{\text {glucose }}}{\mathrm{d} t}=-r_{1}
$$

$$
\begin{gathered}
\frac{\mathrm{d} c_{\text {glucono- } \delta \text {-lactone }}}{\mathrm{d} t}=r_{1}-r_{3} \\
\frac{\mathrm{d} c_{\text {gluconic acid }}}{\mathrm{d} t}=r_{3} \\
\frac{\mathrm{d} c_{\mathrm{O}_{2}}}{\mathrm{~d} t}=-r_{1}+k_{L} a \cdot\left(c_{\mathrm{O}_{2}}^{*}-c_{\mathrm{O}_{2}}\right)+0.5 \cdot r_{2} \\
\frac{\mathrm{d} c_{\mathrm{H}_{2} \mathrm{O}_{2}}}{\mathrm{~d} t}=r_{1}-r_{2}
\end{gathered}
$$

The operational stability decay of the free and immobilized GOD observed during the experiment is described by first order kinetics (Eq.14)

$$
\frac{\mathrm{d} V_{m}}{\mathrm{~d} t}=-k_{d} \cdot V_{m}
$$

Kinetic constants for free and immobilized glucose oxidases and catalase were estimated from independent initial reaction rate measurements, i.e., the dependence of the initial reaction rate on the substrate concentration. The overall oxygen volumetric mass transfer coefficient, $k_{L} a$, was estimated from the independent measurements, acquired in the experimental set-up for the batch reactor. GOD decay rate constant was estimated from the independent experimental results acquired by measuring the enzyme activity via an enzyme assay during the experiment.

The kinetic constants and overall oxygen volumetric mass transfer coefficient were estimated by non-linear regression using the simplex or least squares method implemented in Scientist software ${ }^{25}$. 
The set of optimum parameters were used for the simulation according to the proposed model using the Scientist software. Standard deviations and coefficients of determination as measures of goodness-of-fit were calculated by Scientist $t^{25}$.

\section{Results and discussion}

\section{Enzyme immobilization}

The covalent immobilization of glucose oxidase and catalase on active carrier Eupergit $\mathrm{C}$ was carried out as described previously. Eupergit $\mathrm{C}$ is porous carrier, and during the immobilization process, approximately 75-80 \% enzyme solution soaked onto the carrier, and consequently the mass of the carrier increased significantly. Success of enzyme immobilization is described by the content of enzyme, immobilisation yield, the immobilisation efficiency, and the activity recovery (Eqs. 1-3), as presented in Table 1.

The results showed that the immobilization of the catalase was slightly better than the immobilization of GOD. In the literature, numerous methods for glucose oxidase immobilization can be found with great differences in their success ${ }^{3,8-10,12}$. Efficiency of immobilization usually depends on the $\mathrm{pH}$, temperature, concentration of enzyme in the solution before immobilization, and the time of immobilization. The same method of GOD immobilization on Eupergit $\mathrm{C}$ was used by Mislovičova et $a l .{ }^{9}$ However, because of the lower ratio of enzyme/ carrier in the experimental procedure, the content of GOD on the carrier was twice lower than in our case. They also tested several other supports for covalent immobilization, and among them Eupergit $\mathrm{C}$ proved to be the best regarding operational stability. The adsorption on DOWEX ${ }^{\circledR}$-anionic resins proved to be a very successful method for GOD immobilization $^{13}$. However, the results shown in Table 1 suggest that this immobilization method is satisfactory for GOD. The advantage of immobilization on Eupergit $\mathrm{C}$ is its simplicity. Because of its very convenient features, it has been widely used as an immobilization carrier in industrial applications ${ }^{18,26,27}$.

\section{Kinetics of glucose oxidase}

The glucose oxidase kinetics was determined using initial reaction rate method. Dependence of initial reaction rate on substrate concentration, i.e., glucose (Fig. 2a) and oxygen (Fig. 2b) was measured. Also, the impact of the product gluconic acid on the initial reaction rate was determined (Fig. 2c).

Kinetics of GOD was described with the two-substrate Michaelis-Menten model ${ }^{28}$ with competitive product, i.e., gluconic acid inhibition ${ }^{29}$. The parameters of Michaelis-Menten's kinetic model
(Eq. 6) were evaluated by non-linear regression, and are shown in Table 2. Although not very high, product inhibition that was noticed in the case of free enzyme, was completely reduced by the immobilized GOD, which is one of the benefits of immobilization process ${ }^{30,31}$ and occurred probably due to the small distortion of the enzyme active site after immobilization $^{32}$.

The reaction rate of a reaction catalysed by an immobilised enzyme is often lower than the rate of free enzyme. This is due to the controlling necessity for the substrate to diffuse from the bulk phase to the catalytic surface. The substrate concentration within the microenvironment is lower than that in the bulk due to its depletion by the reaction ${ }^{8,9}$. Michelis-Menten constants are evidently larger for the immobilized enzyme, which is in agreement for immobilized catalyst. The $K_{m}$ in the case of immobilized GOD was significantly affected. The increase in $K_{m}$ of immobilized enzyme in general can be explained as a result of diffusional limitation of the substrate or to conformational changes in the enzyme resulting in a lower affinity of the substrate for the enzyme ${ }^{33,34}$. It is known that kinetic properties of immobilized enzymes have been affected greatly due to diffusional limitations ${ }^{26,35}$ in the $\mathrm{Eu}$ pergit C as a carrier. In our case, $K_{m}$ of glucose was more than four times higher than that of free GOD. Approximately the same increase in $K_{m}$ values was obtained when GOD was covalently immobilized on magnesium silicate ${ }^{3}$. When the concanavalin A-triazine bead cellulose ${ }^{9}$ or poly(styrene-co-glycidyl methacrylate) monodisperse fluorescent microspheres $^{36}$ was used as a support for immobilization

Table 1 - Success of immobilization of GOD and catalase on Eupergit $C$

\begin{tabular}{|c|c|c|}
\hline Enzyme & GOD & Catalase \\
\hline $\begin{array}{l}\text { Content of enzyme }\left[\mathrm{mg}_{\mathrm{GOD}} \mathrm{g}^{-1} \text { wetcarrier }\right. \\
\text { or } \mathrm{cm}^{3}{ }_{\text {catalase }} \mathrm{g}^{-1} \text { wetcarrier }\end{array}$ & 1.571 & 0.063 \\
\hline Yield $[\%]$ & 73.2 & 76.8 \\
\hline Efficiency [\%] & 34.5 & 40.2 \\
\hline Activity recovery [\%] & 25.2 & 30.9 \\
\hline
\end{tabular}

Table 2 - Kinetic parameters of glucose oxidation catalysed by free and immobilised GOD (0.1 M phosphate buffer $\mathrm{pH} 7$, $\left.30{ }^{\circ} \mathrm{C}\right)$

\begin{tabular}{lcc}
\hline \multicolumn{1}{c|}{ Parameter } & Free GOD & Immobilized GOD \\
\hline$V_{m}\left[\mathrm{U} \mathrm{mg}^{-1}\right]$ & $292.092 \pm 8.675$ & $98.75 \pm 5.021$ \\
$K_{m}^{\text {glucose }}[\mathrm{mM}]$ & $19.037 \pm 1.151$ & $84.225 \pm 9.341$ \\
$K_{m}^{\mathrm{O}_{2}}[\mathrm{mM}]$ & $0.010 \pm 0.002$ & $0.0843 \pm 0.0192$ \\
$K_{i}^{\text {gluconic acid }}[\mathrm{mM}]$ & $30.753 \pm 3.659$ & - \\
\hline
\end{tabular}



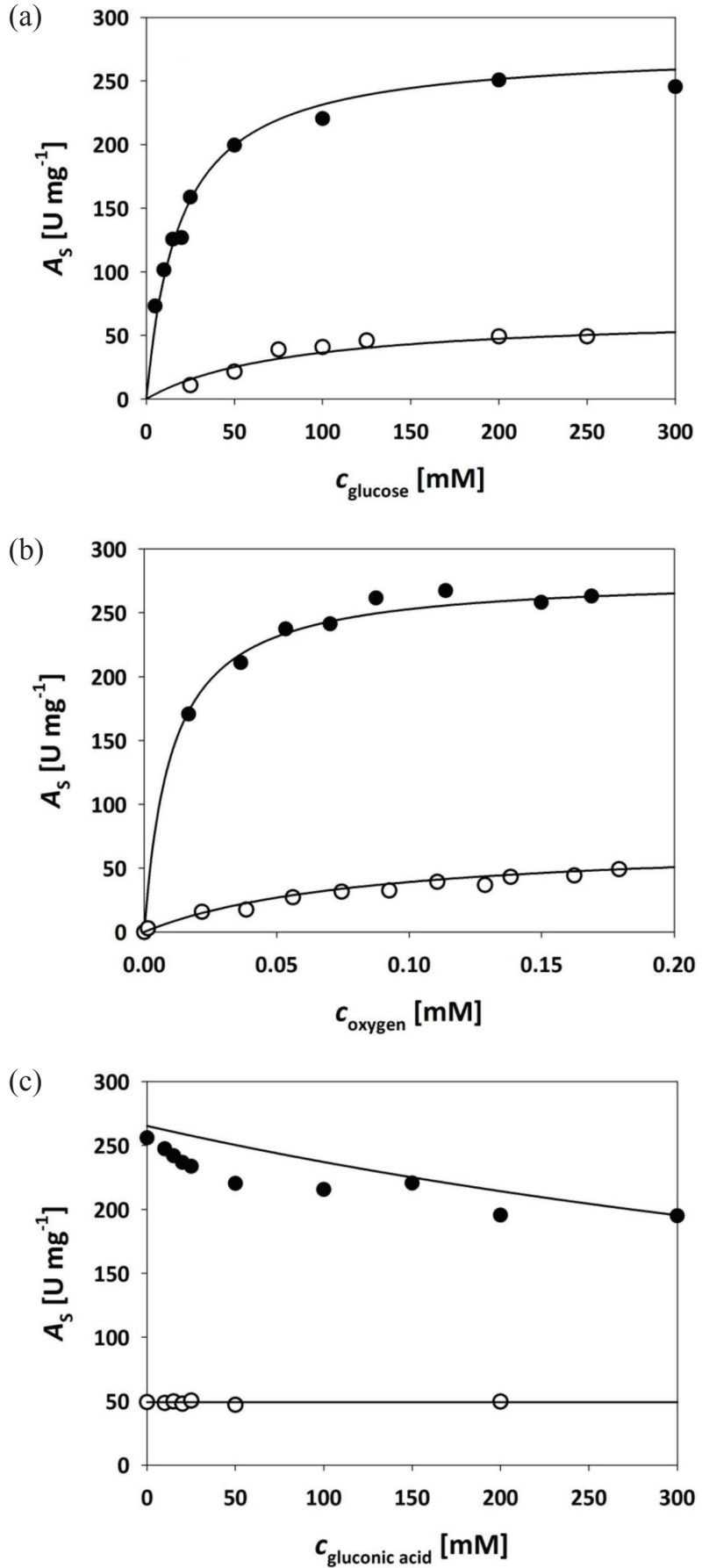

Fig. 2 - Kinetics of free (black circles) and immobilised glucose oxidase (white circles) in the reaction of glucose oxidation (0.1 M phosphate buffer $\left.\mathrm{pH} \mathrm{7,30}{ }^{\circ} \mathrm{C}\right)$. Impact of initial reaction rate on: a) glucose concentration $\left(c_{\mathrm{O}_{2}}=0.1816 \mathrm{mM}\right.$, $\left.\gamma_{\text {free } G O D}=0.26 \mathrm{mg} \mathrm{dm} \mathrm{m}^{-3}, \gamma_{E u-G O D}=0.04 \mathrm{mg} \mathrm{cm}^{-3}\right) ;$ b) oxygen concentration ( $c_{\text {glucose }}=250 \mathrm{mM}, \gamma_{\text {free } G O D}=0.26 \mathrm{mg} \mathrm{dm}^{-3}$, $\left.\gamma_{E_{U}-G O D}=0.02 \mathrm{mg} \mathrm{cm}^{-3}\right)$; c) gluconic acid concentration $\left(c_{O_{2}}=\right.$ $0.1816 \mathrm{mM}, c_{\text {glucose }}=250 \mathrm{mM}, \gamma_{\text {free } G O D}=0.26 \mathrm{mg} \mathrm{dm}^{-3}, \gamma_{E u-G O D}=$ $\left.0.04 \mathrm{mg} \mathrm{cm}^{-3}\right)$.

of GOD, the extent of changes in $K_{m}$ was not as wide as in the case of Eupergit C. In the literature, there is a lack of data for Michaelis-Menten constant for oxygen of immobilized GOD, but in our case, the increase by eight times can be regarded as significant.

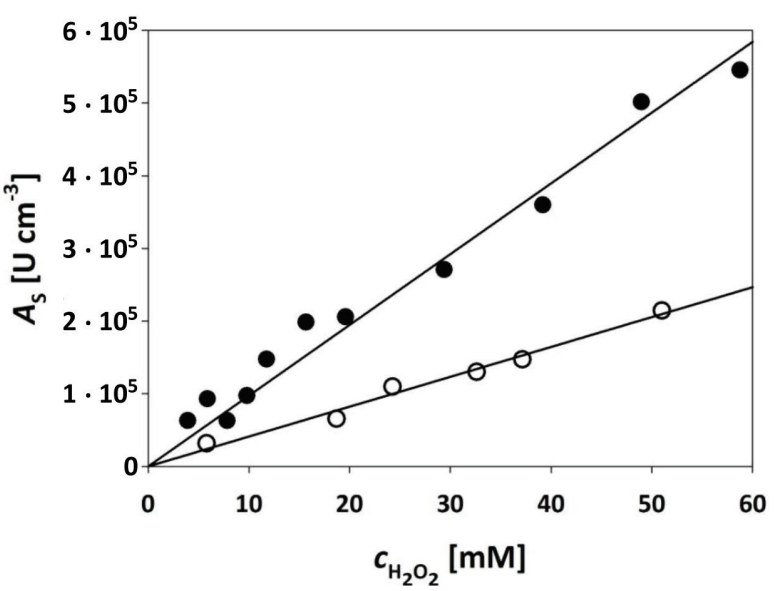

Fig. 3 - Kinetics of free (black circles) and immobilised (white circles) catalase in the reaction of hydrogen peroxide decomposition (0.1 M phosphate buffer $\mathrm{pH} 7,30^{\circ} \mathrm{C}, \varphi_{\text {freecatalase }}=$ $\left.2 \cdot 10^{-7}, \varphi_{E_{1-\text { catalose }}}=4.22 \cdot 10^{-6}\right)$. Impact of initial reaction rate on hydrogen peroxide concentration.

\section{Kinetics of catalase}

Catalase kinetics in the reaction of hydrogen peroxide decomposition was determined by the initial reaction rate method by monitoring the hydrogen peroxide concentration spectrophotometrically $(\lambda=240 \mathrm{~nm})$. Measurements were made at various initial concentrations of hydrogen peroxide at concentrations up to $50 \mathrm{mM}$ (Fig. 3). Higher concentrations were not considered since they were not expected in the reaction medium during the oxidation of glucose.

The kinetics of this reaction was described by the first order (Eq. 7) due to the low specificity of hydrogen peroxide to catalase (high values of Michaelis-Menten constant $)^{15,28,37}$. Estimated reaction rate constants $\left(k_{\text {catalase }}\right)$ were $9738.6 \mathrm{~min}^{-1}$ and $4110.3 \mathrm{~min}^{-1}$ for free and immobilised catalase, respectively.

\section{Spontaneous hydrolysis of glucono- $\delta$-lactone}

Product of glucose oxidation catalysed by glucose oxidase is glucono- $\delta$-lactone that spontaneously hydrolyses into gluconic acid.

In order to determine the kinetics of the spontaneous hydrolysis of glucono- $\delta$-lactone, an experiment was carried out in which the concentrations of glucono- $\delta$-lactone and gluconic acid were monitored (Fig. 4). Based on the experimental data, the parameters were estimated, and the kinetic model of reaction rate was expressed by the equation:

$$
r_{3}=0.0075 \cdot c_{\text {glucono- } \delta \text {-lactone }}^{1.48}
$$

The reaction rate constant and the order of reaction were estimated from experimental data. Order of reaction with the value of 1.48 , indicated that 


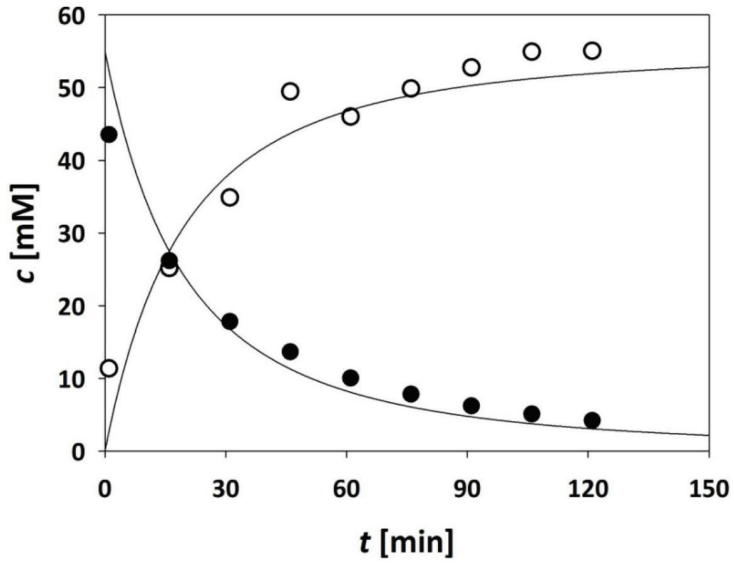

Fig. 4 - Spontaneous hydrolysis of glucono- $\delta$-lactone $(0.1 \mathrm{M}$ phosphate buffer $\left.\mathrm{pH} 7,30^{\circ} \mathrm{C}\right)$. Black circles - glucono- $\delta$-lactone, white circles - gluconic acid, line-model.

the reaction did not go directly from glucose to glucono- $\delta$-lactone, but there were some transition states $^{38}$.

\section{Determination of overall oxygen volumetric mass transfer coefficient at different air flow rates}

Measurements of $k_{L} a$ provide important information about aeration efficiency. Low oxygen solubility can be a bottleneck in oxygen-dependent processes. This parameter is essential to ensure that process conditions are such that an adequate supply of oxygen is available to reach desirable process metrics. By increasing the oxygen flow rate or by intensifying mixing, higher oxygen transfer rate can be achieved ${ }^{39,40}$.

The results of $k_{L} a$ determination at different air flow rates are presented in Table 3. $k_{L} a$ was determined in both reactors in which the reactions with immobilized and free GOD were performed. The differences in these types of reactors were in the mode of mixing and reaction volume. Results revealed that the $k_{L} a$ value linearly depended on the air flow rate. Higher oxygen mass transfer in the reactor where immobilized enzyme was used was due to the smaller volume and higher liquid-air interface (larger diameter) of the reactor. Estimate $k_{L} a$ values are in accordance with oxygen transfer characteristics for the small reactors and the mixing method $^{41}$.

\section{Biotransformation of D-glucose to D-gluconic acid}

Oxidase used oxygen as a second substrate in the reaction. The initial reaction rate increased with the oxygen concentration ${ }^{42}$. To maintain a sufficient amount of oxygen in the reactor, it is essential to ensure its supply. In some cases, aeration can cause enzyme inactivation, and it is usually attributed to the combined effect of shear rate and the presence
Table 3 -Oxygen volume transfer coefficients, $k_{t} a$, at different air flow rates in the batch reactors $\left(30^{\circ} \mathrm{C}, 0.1 \mathrm{M}\right.$ phosphate buffer $\mathrm{pH} 7$, immobilized enzyme: shaker, $30 \mathrm{~cm}^{3}$; free enzyme: magnetic stirrer, $50 \mathrm{~cm}^{3}$ )

\begin{tabular}{c|cc}
\hline \multirow{2}{*}{$q_{\mathrm{V}}\left[\mathrm{dm}^{3} \mathrm{~h}^{-1}\right]$} & \multicolumn{2}{|c}{$k_{L} a\left[\mathrm{~min}^{-1}\right]$} \\
\cline { 2 - 3 } & Immobilized enzyme & Free enzyme \\
\hline 0 & 0.890 & 0.106 \\
15 & 1.625 & 0.933 \\
30 & 2.360 & 1.741 \\
\hline
\end{tabular}

of the air-liquid interface ${ }^{43}$. This combination has been proved to cause deactivation of some proteins due to their irreversible aggregation at the air-liquid interface ${ }^{44}$. Besides aeration, the increased oxygen concentration in the reactor can also cause a decrease in enzyme activity. This was observed with the enzyme carbohydrate oxidase, in which case deactivation was not affected by increased air flow but only by oxygen concentration in the reactor ${ }^{42}$. Glucose oxidase, according to the available data in the literature, shows deactivation upon oxygen concentration $^{6}$, as well as the presence of gas bubbles caused by stirring ${ }^{7}$, but there is a lack of information considering aeration of reactor. In this work, we examined the impact of aeration on glucose oxidase stability for free and immobilized enzyme. Immobilization of enzyme on porous support proved to be successful in preventing enzyme inactivation caused by aeration ${ }^{7,14,32}$. Therefore, the experiments of glucose oxidation with free and immobilized enzymes were carried out at defined air flow rates.

\section{Reactions with free GOD}

Figs. 5 and 6 present the results of the experiments with and without aeration catalysed by free GOD. In all cases, oxygen concentration was very low and below enzyme saturation value $(<0.01 \mathrm{mM})$. The experiment without aeration (Fig. 5) was done as a single batch, and approximately 1400 minutes were required to achieve complete glucose conversion $(50 \mathrm{mM})$. The experiments with aeration were performed as a repetitive batch experiment with two glucose additions. This type of experiment proved to be useful for testing the prolonged enzyme stability $^{45}$. Even though oxygen concentration in the reactor was low, the constant air supply ensured considerably faster reaction. The second experiment (Fig. 6a, $q_{\mathrm{v}}=15 \mathrm{dm}^{3} \mathrm{~h}^{-1}$ ) lasted $450 \mathrm{~min}$, while the third one with the highest aeration level (Fig. 6c, $q_{\mathrm{v}}=30 \mathrm{dm}^{3} \mathrm{~h}^{-1}$ ) lasted approximately $350 \mathrm{~min}$.

Activity of glucose oxidase was monitored during the experiments and its operational stability decay was described by first order kinetics ${ }^{11}$ (Eq. 14). The values of the operational stability decay 


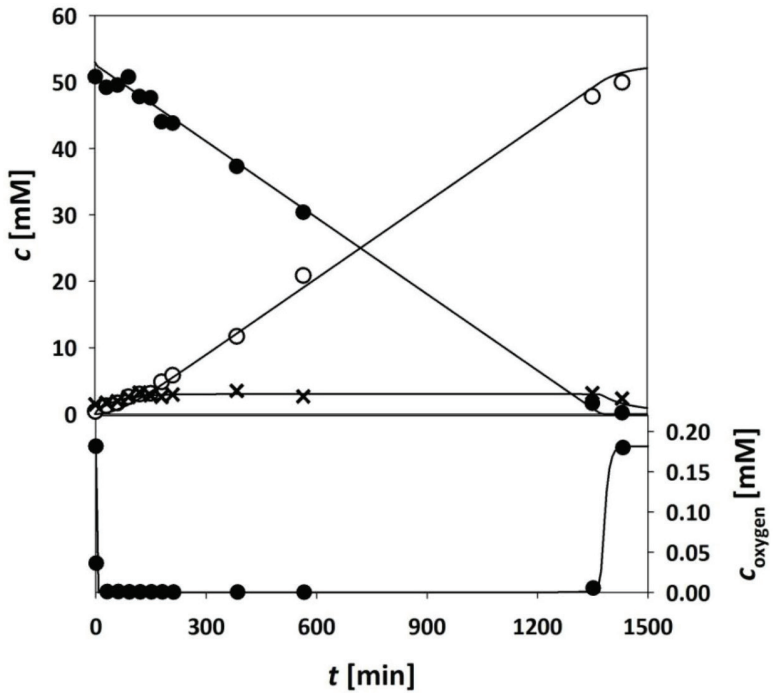

Fig. 5 - Glucose oxidation catalysed by free GOD from Aspergillus niger in the batch reactor $\left(c_{\text {glucose })}=50 \mathrm{mM}, \gamma_{\text {free } G O D}=\right.$ $0.04 \mathrm{mg} \mathrm{cm}^{-3}, \varphi_{\text {catalase }}=0.002,0.1 \mathrm{M}$ phosphate buffer $\mathrm{pH}=7$; $30{ }^{\circ} \mathrm{C} ; V=50^{\circ} \mathrm{cm}^{3}$ ) without aeration (upper graph: black circle-glucose, white circles-gluconic acid, $x$-glucono- $\delta$-lactone; bottom graph - oxygen).

rate constants in Table 4 show an increase with the increase in the air flow rate, as well as with an increase in $k_{L} a$. Since the oxygen level was very low in all the experiments, it can be concluded that the air flow rate is critical for the enzyme activity decay. This proved that the operational stability decrease in the case of GOD was due to the interaction with gas bubbles ${ }^{15}$, meaning that aeration had an impact on GOD stability.

Model simulations presented in Figs. 5 and 6 were done using proposed mathematical model (Eqs. 6-15) with the independently estimated kinetic parameters (Table 2), operational stability decay constants (Table 4), and oxygen volumetric mass transfer coefficient (Table 3). The goodness-of-fit statistics provided by Scientist indicated that a satisfying fit was obtained (coefficient of determination was 0.950-0.994 and standard deviation 0.5921.055).

\section{Reactions with immobilized GOD on Eupergit C}

To compensate partially the loss of enzyme activity during immobilization process (Table 1), somewhat higher GOD concentrations were used in these experiments, but overall activity was approximately 2.3 times lower compared with the experiments catalysed by free enzyme. All experiments were run in the repetitive batch mode.

To avoid covalent bond breakage between enzyme and carrier, the experiments with immobilized enzyme were carried out on a shaker ${ }^{46}$ instead of magnetic stirrer. Due to differences in geometry of the reactors, oxygen transfer rate was higher in the (a)

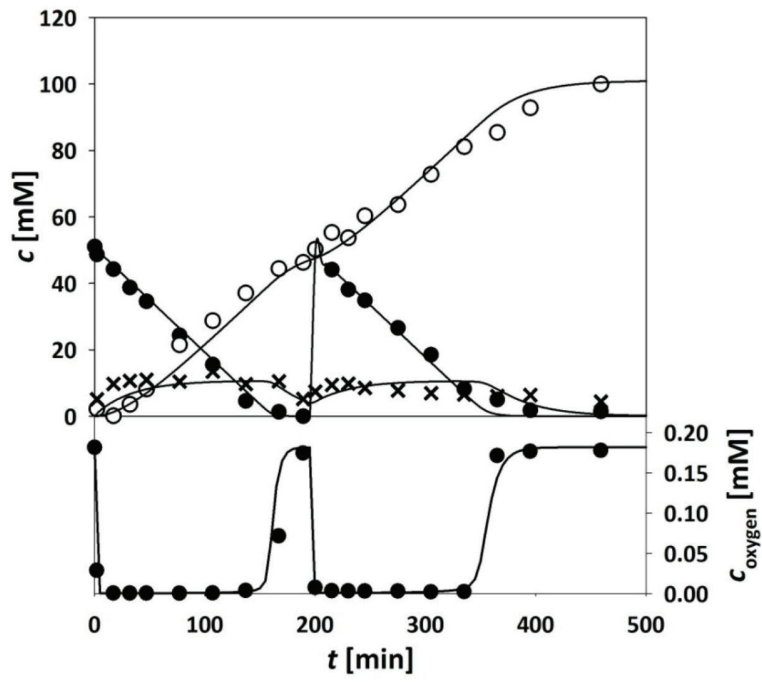

(b)

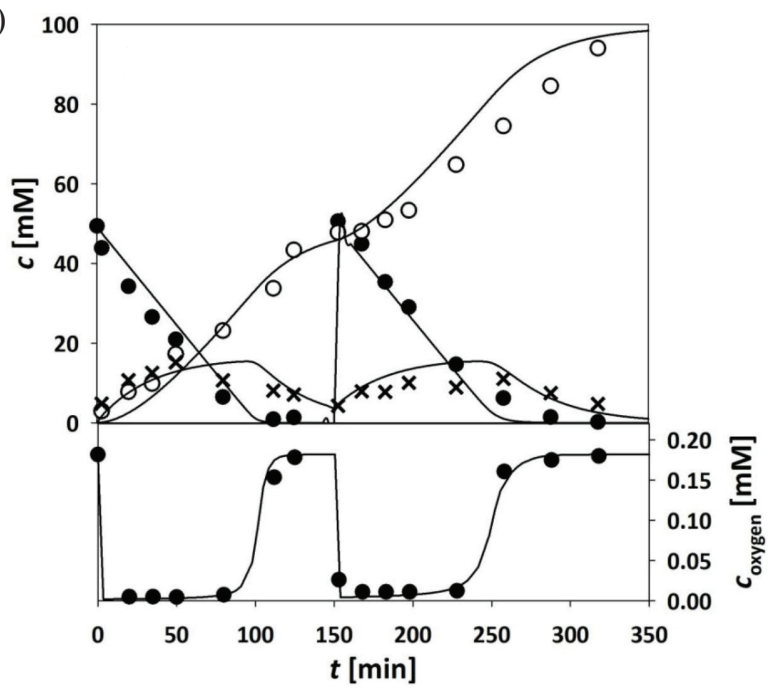

Fig. 6-Glucose oxidation catalysed by free GOD from Aspergillus niger in the batch reactor $\left(c_{\text {glucose } 0}=50 \mathrm{mM}, \gamma_{\text {free } G O D}=\right.$ $0.04 \mathrm{mg} \mathrm{cm}^{-3}, \varphi_{\text {catalase }}=0.002,0.1 \mathrm{M}$ phosphate buffer $\mathrm{pH}=7$; $30{ }^{\circ} \mathrm{C} ; V_{\text {reactor }}=50 \mathrm{~cm}^{3}$ ) at the aeration level of: a) $15 \mathrm{dm}^{3} \mathrm{~h}^{-1}$ b) $30 \mathrm{dm}^{3} \mathrm{~h}^{-1}$ (upper graph: black circle - glucose, white circles -gluconic acid, $x$-glucono- $\delta$-lactone; bottom graph-oxygen).

Table 4-Free GOD operational stability decay rate constants at different aeration rates estimated from the independent activity measurements

\begin{tabular}{ccc}
\hline$q_{v}\left[\mathrm{dm}^{3} \mathrm{~h}^{-1}\right]$ & $k_{L} a\left[\mathrm{~min}^{-1}\right]$ & $k_{d}\left[\mathrm{~min}^{-1}\right]$ \\
\hline 0 & 0.106 & $1.01 \cdot 10^{-4}$ \\
15 & 0.933 & $6.57 \cdot 10^{-4}$ \\
30 & 1.741 & 0.001794 \\
\hline
\end{tabular}

experiments with the immobilized enzymes, compared with the one with free GOD (Table 3) at the same aeration conditions. Results of the glucose oxidation catalysed by immobilized GOD are shown in Figs. 7 and 8. 


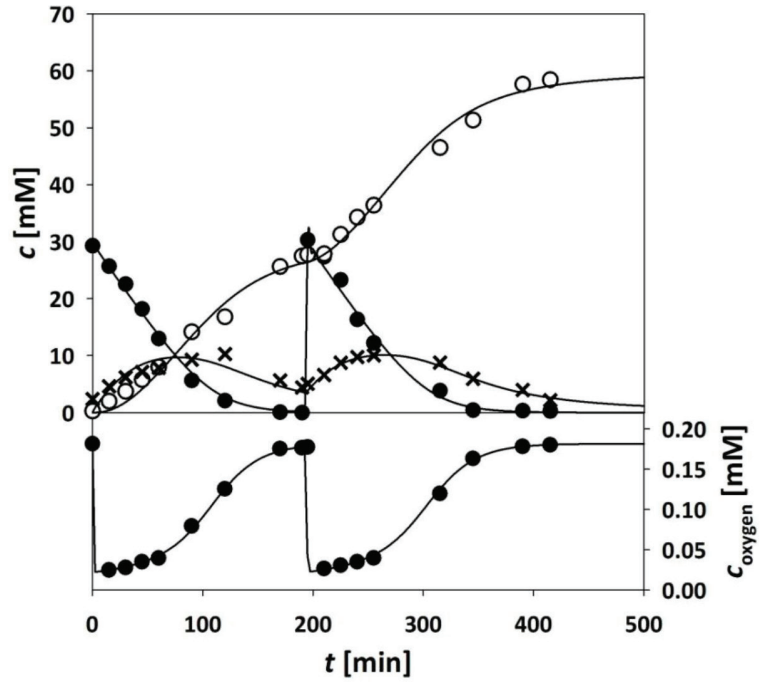

Fig. 7 - Glucose oxidation catalysed by immobilized GOD from Aspergillus niger in the batch reactor $\left(c_{\text {glucose } 0}=30-40 \mathrm{mM}\right.$, $\gamma_{E^{\prime}-}=0.05 \mathrm{mg} \mathrm{cm}^{-3}, \varphi_{E_{u-c}}=0.002,0.1 \mathrm{M}$ phosphate buffer $\mathrm{pH}=7 ; 30^{\circ} \mathrm{C} ; V_{\text {reactor }}=30 \mathrm{~cm}^{3}$ ) without aeration (upper graph: black circle - glucose, white circles-gluconic acid, $x$ - glucono- $\delta$-lactone; bottom graph-oxygen).

Table 5 -Immobilized GOD operational stability decay rate constants at different aeration rates estimated from the independent activity measurements

\begin{tabular}{ccc}
\hline$q_{v}\left[\mathrm{dm}^{3} \mathrm{~h}^{-1}\right]$ & $k_{L} a\left[\mathrm{~min}^{-1}\right]$ & $k_{d}\left[\mathrm{~min}^{-1}\right]$ \\
\hline 0 & 0.890 & $8.89 \cdot 10^{-5}$ \\
15 & 1.625 & $1.31 \cdot 10^{-4}$ \\
30 & 2.360 & $1.36 \cdot 10^{-4}$ \\
\hline
\end{tabular}

In the experiment (Fig. 7) without aeration, the oxygen concentration was enough to ensure satisfying reaction rate due to higher oxygen transfer, and because of the fact that the experiment with the immobilized enzymes lasted three times shorter than that with the free enzyme (Fig. 5). Differences in $k_{L} a$ values were not so pronounced at higher air flows. Despite lower activity of the enzyme in the reactor, reactions with immobilized enzymes lasted shorter (Fig. 8) or the same as that with the free enzyme (Fig. 6). The reason for this is better oxygen transfer and lower enzyme operational decay rates. The operational decay rate constants were estimated from independent activity measurement (Table 5).

According to results of the operational decay rate constants (Tables 4 and 5), a significant positive impact of immobilization process on GOD stability at higher flow rates was observed. At a flow rate of 15 and $30 \mathrm{dm}^{3} \mathrm{~h}^{-1}, k_{d}$ was reduced by 5 and 13 times, respectively. Decrease in $k_{d}$ in the experiment without aeration was not so prominent, but these experiments are hard to compare. In experiment with immobilized enzyme, the $k_{L} a$ was almost (a)

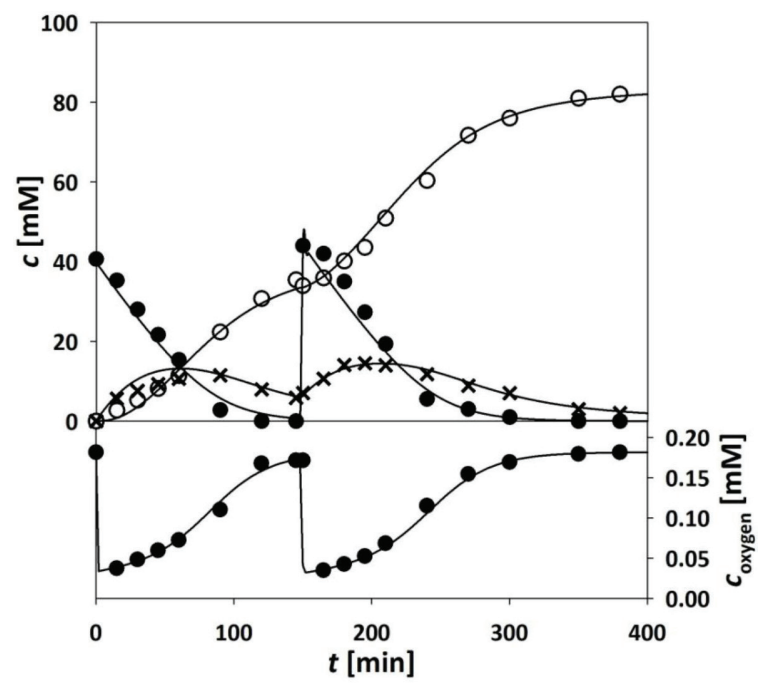

(b)

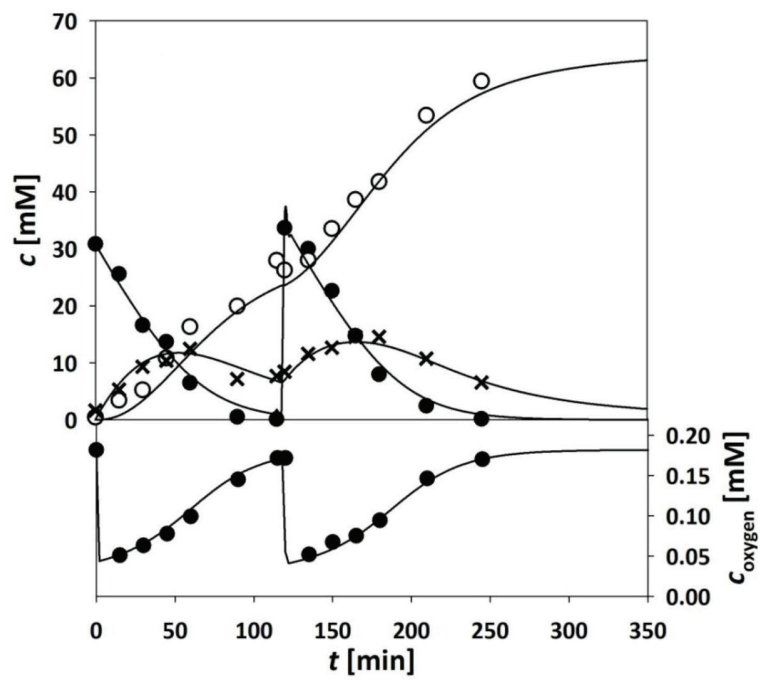

Fig. 8 - Glucose oxidation catalysed by immobilized GOD from Aspergillus niger in the batch reactor $\left(c_{\text {glucosen }}=30-40 \mathrm{mM}\right.$, $\gamma_{E u-G O D}=0.05 \mathrm{mg} \mathrm{cm}^{-3}, \varphi_{\text {Eu-catalase }}=0.002,0.1 \mathrm{M}$ phosphate buffer $\left.\mathrm{pH}=7 ; 30^{\circ} \mathrm{C} ; V_{\text {reactor }}=30 \mathrm{~cm}^{3}\right)$ at the aeration level of: a) $15 \mathrm{dm}^{3} \mathrm{~h}^{-1}$ b) $30 \mathrm{dm}^{3} h^{-1}$ (upper graph: black circle - glucose, white circles -gluconic acid, $x$ - glucono- $\delta$-lactone; bottom graph-oxygen).

nine times higher than in the same experiment with the free enzyme. This enabled higher oxygen level in the reactor and consequently a faster reaction. Due to previous findings ${ }^{6}$, stability of GOD is also affected by the oxygen presence in the reactor. According to our results, the immobilization of GOD on Eupergit proved to be successful in eliminating this negative effect on its stability.

Proposed mathematical model (Eqs. 6-15) and the independently estimated kinetic parameters (Table 2), operational stability decay constants (Table 5), and oxygen volumetric mass transfer coefficient (Table 4), well-described the reactions catalysed by immobilized enzyme (coefficient of determination was $0.930-0.991$ and standard deviation 0.605-1.105) (Figs. 7 and 8). 
Considering the obtained results, it can be concluded that immobilization of GOD on Eupergit C leads to its enhanced stability toward aeration and oxygen concentration in the reactor. The positive stability impact of immobilised enzyme is more pronounced at higher flow rates that contribute to a faster glucose oxidation reaction catalysed by glucose oxidase. A possible explanation why immobilization prevents enzyme operational stability decay is a diffusional limitation of oxygen to enzyme active site, which is evident from the increase in $K_{\mathrm{m}}^{\mathrm{O}_{2}}$ value for immobilized enzyme (Table 2). By this impact of oxygen as well, the oxygen bubble on the enzyme stability is decreased ${ }^{14}$.

Besides immobilization, the impact of aeration on enzyme stability can be reduced by using several bubbleless oxygenation methods. These techniques include dynamic membrane aeration ${ }^{47}$, use of redox mediator that is regenerated by laccase ${ }^{2}$ or the new technology involving oxygen photosynthesis by water oxidation catalysed by alkane monooxygenase $^{48}$.

\section{Conclusion}

The reaction rate of GOD is increased by aeration, but the stability of the free enzyme decreases due to the interaction with gas bubbles. The enzyme deactivation rate increases with the air flow rate. The immobilization of GOD on the porous carrier Eupergit $\mathrm{C}$ has been shown to be very effective for enzyme stabilization at the high aeration level. Enzyme immobilization lowered activity and affinity towards substrates (glucose and oxygen), as well eliminated gluconic acid (product) inhibition in the reaction of glucose oxidation. The reactions in the batch reactor were very well described by the developed mathematical model with estimated kinetic parameters and operational stability decay constants.

$$
\begin{array}{ll}
\text { Lis } \mathbf{t} \text { of } & \mathbf{s} \mathbf{y} \mathbf{m} \mathbf{b} \text { ols } \\
A_{S} & - \text { specific activity of enzyme, } \mathrm{U} \mathrm{mg}^{-1}, \mathrm{U} \mathrm{cm}^{-3} \\
c & - \text { concentration, } \mathrm{mM} \\
c^{*} & - \text { saturation concentration, } \mathrm{mM} \\
k & - \text { reaction rate constant of the first order, } \mathrm{min}^{-1} \\
k_{n} & - \text { reaction rate constant of the } \mathrm{n} \mathrm{order}, \\
& \text { min } \mathrm{mM}^{1-\mathrm{n}} \\
k_{d} & - \text { operational stability decay rate constant of } \\
& \text { the first order, min } \\
k_{L} a & - \text { oxygen volume transfer coefficient, } \mathrm{min}^{-1} \\
K_{i} & - \text { inhibition constant, } \mathrm{mM} \\
K_{m} & - \text { Michaelis constant, } \mathrm{mM} \\
\eta & - \text { order of the reaction, }-
\end{array}
$$

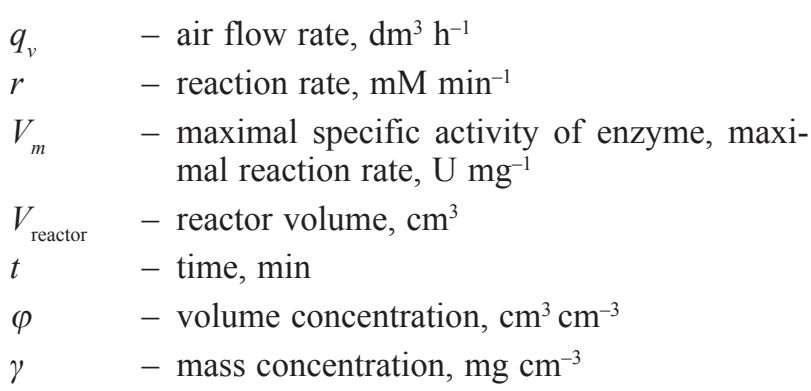

\section{Abbreviations}

$\begin{array}{ll}\mathrm{Eu} & - \text { Eupergit } \mathrm{C} \\ \mathrm{GOD} & - \text { glucose oxidase }\end{array}$

\section{References}

1. Pedersen, A. T., De Carvalho, T. M., Sutherland, E., Rehn, G., Ashe, R., Woodley, J. M., Characterization of a continuous agitated cell reactor for oxygen dependent biocatalysis, Biotechnol. Bioeng. 114 (2017) 1222. doi: https://doi.org/10.1002/bit.26267

2. Van Hecke, W., Ludwig, R., Dewulf, J., Auly, M., Messiaen, T., Haltrich, D., Van Langenhovea, H., Bubble-free oxygenation of a bienzymatic system: Effect on biocatalyst stability, Biotechnol. Bioeng. 102 (2009) 122. doi: https://doi.org/10.1002/bit.22042

3. Ozyilmaz, G., Tukel, S. S., Alptekin, O., Activity and storage stability of immobilized glucose oxidase onto magnesium silicate, J. Mol. Catal. B: Enzym. 35 (2005) 154. doi: https://doi.org/10.1016/j.molcatb.2005.07.001

4. Dubey, M. K., Zehra, A., Aamir, M., Meena, M., Ahirwal, L., Singh, S., Improvement strategies, cost effective production, and potential applications of fungal glucose oxidase (GOD): Current updates, Front. Microbiol. 8 (2017) 1032. doi: https://doi.org/10.3389/fmicb.2017.01032

5. Cañete-Rodríguez, A. M., Santos-Dueñas, I. M., Jiménez-Hornero, J. E., Ehrenreich, A., Liebl, W., GarciaGarcía, I., Gluconic acid: Properties, production methods and applications-an excellent opportunity for agro-industrial by-products and waste bio-valorization, Process. Biochem. 51 (2016) 1891. doi: https://doi.org/10.1016/j.procbio.2016.08.028

6. Venugopal, R., Saviue, B. A., The effect of oxygen upon the kinetics of glucose oxidase inactivation, Can. J. Chem. Eng. 71 (1993) 917.

doi: https://doi.org/10.1002/cjce.5450710613

7. Betancor, L., Fuentes, M., Dellamora-Ortiz, G., López-Gallego, F., Hidalgo, A., Alonso-Morales, N., Mateo, C., Guisán, J. M., Fernández-Lafuente, R., Dextranaldehyde coating of glucose oxidase immobilized on magnetic nanoparticles prevents its inactivation by gas bubbles, J. Mol. Catal. B: Enzym. 32 (2005) 97.

doi: https://doi.org/10.1016/j.molcatb.2004.11.003

8. Rauf, S., Ihsan, A., Akhtar, K., Ghauri, M. A., Rahman, M., Anwar, M. A., Khalid, A. M., Glucose oxidase immobilization on a novel cellulose acetate-polymethylmethacrylate membrane, J. Biotechnol. 121 (2006) 351. doi: https://doi.org/10.1016/j.jbiotec.2005.08.019

9. Mislovičová, D., Michálková, E., Vikartovská A., Immobilized glucose oxidase on different supports for biotransformation removal of glucose from oligosaccharide mixtures, Process Biochem. 42 (2007) 704. doi: https://doi.org/10.1016/j.procbio.2006.11.001 
10. Widi, R. K., Trisulo, D. C., Budhyantoro, A., Chrisnasari, $R$., Preparation of immobilized glucose oxidase wafer enzyme on calcium bentonite modified by surfactant, IOP Conf. Ser.: Mater. Sci. Eng. 223 (2017) 012050.

11. Bao, J., Koumatsu, K., Furumoto, K., Yoshimoto, M., Fukunaga, K., Nakao, K., Deactivation kinetics of immobilized glucose oxidase for production of calcium gluconate in an external loop air lift bioreactor, Biochem. Eng. J. 22 (2004) 33 doi: https://doi.org/10.1016/j.bej.2004.08.001

12. Sisak, C., Csanádi, Z., Rónay, E., Szajáni B., Elimination of glucose in egg white using immobilized glucose oxidase, Enzyme Microb. Technol. 39 (2006) 1002. doi: https://doi.org/10.1016/j.enzmictec.2006.02.010

13. Tomotani, E. J., Vitolo, M., Immobilized glucose oxidase as a catalyst to the conversion of glucose into gluconic acid using a membrane reactor, Enzyme Microb. Technol. 40 (2007) 1020. doi: https://doi.org/10.1016/j.enzmictec.2006.07.039

14. Nahalka, J., Dib, I., Nidetzky, B., Encapsulation of Trigonopsis variabilis D-amino acid oxidase and fast comparison of the operational stabilities of free and immobilized preparations of the enzyme, Biotechnol. Bioeng. 99 (2008) 251. doi: https://doi.org/10.1002/bit.21579

15. Findrik, Z., Vrsalović Presečki, A., Vasić-Rački, Đ., The influence of aeration on activity and operational stability of two snake venom amino acid oxidases, Biochem. Eng. J. 60 (2012) 91 doi: https://doi.org/10.1016/j.bej.2011.10.008

16. Mateo, C., Abian, O., Fernandez-Lafuente, R., Guisan, J. $M$., Increase in conformational stability of enzymes immobilized on epoxy-activated supports by favoring additional multipoint covalent attachment, Enzyme Microb. Technol. 26 (2000) 509.

doi: https://doi.org/10.1016/S0141-0229(99)00188-X

17. Braga, A. R. C., Silva, M. F., Oliveira, J. V., Reicheld, H. Kalila, S. J., A new approach to evaluate immobilization of beta-galactosidase on Eupergit (R) C: Structural, kinetic, and thermal characterization, Quim. Nova 37 (2014) 796.

18. Ali, S., Zafar, W., Shafiq, S., Manzoor, M., Enzymes immobilization: An overview of techniques, support materials and its applications, Int. J. Scient. Technol. Res. 6 (2017) 64.

19. Tibhe, J. D., Fu, H., Noël, T., Wang, Q., Meuldijk, J., Hessel, $V$., Flow synthesis of phenylserine using threonine aldolase immobilized on Eupergit support, Beilstein J. Org. Chem. 9 (2013) 2168. doi: https://doi.org/10.3762/bjoc.9.254

20. Vasić-Rački, Đ., Findrik, Z., Vrsalović Presečki, A., Modelling as a tool of enzyme reaction engineering for enzyme reactor development, Appl. Microbiol. Biotechnol. 91 (2011) 845 .

doi: https://doi.org/10.1007/s00253-011-3414-0

21. Sheldon, R. A., van Peltb, S., Enzyme immobilisation in biocatalysis: Why, what and how, Chem. Soc. Rev. 42 (2013) 6223. doi: https://doi.org/10.1039/C3CS60075K

22. U.S. Geological Survey Water-Resources Investigations Reports Book 9, 4/98, 1998, pp 27-38.

23. Lartillot, S., Kedziora, P., Athias, A., Purification and characterization of a new fungal catalase, Prep. Biochem. 18 (1988) 241. doi: https://doi.org/10.1080/00327488808062526

24. Ory, I., Romero, L. E., Cantero, D., Laboratory scale equipment for the determination of $k_{L} a$ in bio-reactors, Bioprocess Eng. 20 (1999) 73.

25. SCIENTIST handbook, Salt Lake City: Micromath ${ }^{\circledR} 1986-$ 1995.
26. Dwevedi, A., Basics of Enzyme Immobilization. In: Enzyme Immobilization. Springer, Cham, Switzerland, 2016 , pp 21-44. doi: https://doi.org/10.1007/978-3-319-41418-8_2

27. Katchalski-Katzir, E., Kraemer, D. M., Eupergit ${ }^{\circledR}$ C, a carrier for immobilization of enzymes of industrial potential, J. Mol. Catalysis B: Enzymatic, 10 (2000) 157. doi: https://doi.org/10.1016/S1381-1177(00)00124-7

28. Reuss, M. Buchholz, K., Analysis of the coupled transport, reaction, and deactivation phenomena in the immobilized glucose oxidase and catalase system, Biotechnol. Bioeng. 21 (1979) 2061. doi: https://doi.org/10.1002/bit.260211112

29. Mirón, J., González, M. P., Vázquez, J. A., Pastrana, L., Murado, M. A., A mathematical model for glucose oxidase kinetics, including inhibitory, deactivant and diffusional effects, and their interactions, Enzyme Microb. Technol. 34 (2004) 513 . doi: https://doi.org/10.1016/j.enzmictec.2003.12.003

30. Guzik, U., Hupert-Kocurek, K., Wojcieszyńska, D., Immobilization as a strategy for improving enzyme properties-application to oxidoreductases, Molecules 19 (2014) 8995. doi: https://doi.org/10.3390/molecules 19078995

31. Freitas, F. F., Marquez, L. D. S., Ribeiro, G. P., Brandão, G. C., Cardoso, V. L., Ribeiro, E. J., Optimization of the immobilization process of $\beta$-galatosidade by combined entrapment-cross-linking and the kinetics of lactose hydrolysis, Braz. J. Chem. Eng. 29 (2012) 15. doi: https://doi.org/10.1590/S0104-66322012000100002

32. Findrik, Z., Tusić, M., Vasić-Rački, Đ., Stabilization of D-amino acid oxidase via covalent immobilization and mathematical model of D-methionine oxidative deamination catalyzed by immobilized enzyme, Chem. Biochem. Eng. Q. 30 (2016) 93. doi: https://doi.org/10.15255/CABEQ.2015.2189

33. Spinelli, D., Fatarella, E., DiMichele, A., Pogni, R., Immobilization of fungal (Trametes versicolor) laccase onto Amberlite IR-120 H beads: Optimization and characterization, Process Biochem. 48 (2013) 218. doi: https://doi.org/10.1016/j.procbio.2012.12.005

34. Fatarella, E., Spinelli, D., Ruzzante, M., Pogni, R., Nylon 6 film and nanofiber carriers: Preparation and laccase immobilization performance, J. Mol. Catalysis B: Enzymatic 102 (2014) 41 doi: https://doi.org/10.1016/j.molcatb.2014.01.012

35. Tischer, $W$., Kasche, $V$., Immobilized enzymes: Crystals or carriers?, TIBTECH 17 (1999) 326. doi: https://doi.org/10.1016/S0167-7799(99)01322-0

36. Hou, X., Liu, B., Deng, X., Zhang, B., Chen, H., Luo, R., Covalent immobilization of glucose oxidase onto poly(styrene-co-glycidylmethacrylate) monodisperse fluorescent microspheres synthesized by dispersion polymerization, Anal. Biochem. 368 (2007) 100. doi: https://doi.org/10.1016/j.ab.2007.04.034

37. Aebi, H., Bergmeyer, H. U., Methods of Enzymatic Analysis, Verlag Chemie, Weinheim \& Academic Press, New York/London, 1974, pp. 673. doi: https://doi.org/10.1016/B978-0-12-091302-2.50032-3

38. Pocker, Y., Green, E., Hydrolysis of D-glucono- $\delta$-lactone. I. General acid-base catalysis, solvent deuterium isotope effects, and transition state characterization, J. Am. Chem. Soc. 95 (1973) 113. doi: https://doi.org/10.1021/ja00782a019

39. Garcia-Ochoa, F., Gomez, E., Bioreactor scale-up and oxygen transfer rate in microbial processes: An overview, Biotechnol. Adv. 27 (2009) 153. doi: https://doi.org/10.1016/j.biotechadv.2008.10.006 
40. Klein, J., Rosenberg, M., Markoš, J., Dolgoš, O., Krošslak, $M$., Krištofikova, L., Biotransformation of glucose to gluconic acid by Aspergillus niger - study of mass transfer in an air lift bioreactor, Biochem. Eng. J. 10 (2002) 197. doi: https://doi.org/10.1016/S1369-703X(01)00181-4

41. Kirk, T. V., Szita, N., Oxygen transfer characteristics of miniaturized bioreactor systems, Biotechnol. Bioeng. 110 (2013) 1005. doi: https://doi.org/10.1002/bit.24824

42. Nordkvist, M., Nielsen, P. M., Villadsen, J., Oxidation of lactose to lactobionic acid by a Microdochium nivale carbohydrate oxidase: Kinetics and operational stability, Biotechnol. Bioeng. 97 (2007) 694

doi: https://doi.org/10.1002/bit.21273

43. Ludwig, R., Ozga, M., Zámocky, M., Peterbauer, C., Kulbe, $K$. D., Haltrich, D., Continuous enzymatic regeneration of electron acceptors used by flavoenzymes: Cellobiose dehydrogenase-catalyzed production of lactobionic acid as an example, Biocat. Biotrans. 22 (2004) 97. doi: https://doi.org/10.1080/10242420410001692787

44. Maa, Y. F., Hsu, C. C., Protein denaturation by combined effect of shear and air-liquid interface, Biotechnol. Bioeng. 54 (1997) 503.

doi: https://doi.org/10.1002/(SICI)1097-0290(19970620)54:6 $<503::$ AID-BIT 1 $>3.0 . \mathrm{CO} ; 2-\mathrm{N}$
45. Švarc, A., Valinger, D., Vasić-Rački, Đ., Presečki, A. V., Stereoselective synthesis of phenylpropane 1,2-diols from (S)-2-hydroxypropiophenone by NADH-dependent oxidoreductases, Biochem. Eng. J. 103 (2015) 250. doi: https://doi.org/10.1016/j.bej.2015.07.012

46. Mahajan, R., Gupta, V. K., Sharma, J., Comparison and suitability of gel matrix for entrapping higher content of enzymes for commercial applications, Indian. J. Pharm. Sci. 72 (2010) 223.

doi: https://doi.org/10.4103/0250-474X.65010

47. Van Hecke, W., Haltrich, D., Frahmd, B., Brode, H., Dewulf, J., Van Langenhovea, H., Ludwig, R., A biocatalytic cascade reaction sensitive to the gas-liquid interface: Modeling and upscaling in a dynamic membrane aeration reactor, J. Mol. Catal. B: Enzym. 68 (2011) 154. doi: https://doi.org/10.1016/j.molcatb.2010.10.004

48. Hoschek, A., Bühler, B., Schmid, A., Overcoming the gasliquid mass transfer of oxygen by coupling photosynthetic water oxidation with biocatalytic oxyfunctionalization, Angew. Chem. Int. Ed. 56 (2017) 15146. doi: https://doi.org/10.1002/anie.201706886 